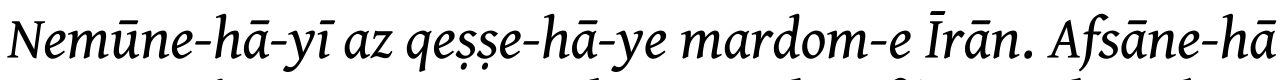
va qeșșe-hā-ye ìrānī. Gerdāvarande Afs̃īn Nāderī, bar pāye-ye asnād-e Pažūheškade-ye Mardom-šenāsī, Sāzmān-e Mīrāṭ-e Farhangī-e Kešvar, Tehrān, Našre Qeșṣe, 1383/2004, 432 p. (table de transcription, glossaire, index).

\title{
Marina Gaillard
}

\section{OpenEdition \\ Journals}

\section{Édition électronique}

URL : http://journals.openedition.org/abstractairanica/6445

DOI : 10.4000/abstractairanica.6445

ISSN : 1961-960X

Éditeur :

CNRS (UMR 7528 Mondes iraniens et indiens), Éditions de l'IFRI

Édition imprimée

Date de publication : 15 mai 2006

ISSN : 0240-8910

\section{Référence électronique}

Marina Gaillard, « Nemūne-hā-yī az qeșșe-hā-ye mardom-e İrān. Afsāne-hā va qeșșe-hā-ye îrānī. Gerdāvarande Afšīn Nāderī, bar pāye-ye asnād-e Pažūheškade-ye Mardom-šenāsī, Sāzmān-e Mīrāte-e Farhangī-e Kešvar, Tehrān, Našr-e Qeșșe, 1383/2004, 432 p. (table de transcription, glossaire, index). », Abstracta Iranica [En ligne], Volume 27 | 2006, document 314, mis en ligne le 02 janvier 2007, consulté le 25 septembre 2020. URL : http://journals.openedition.org/abstractairanica/6445 ; DOI : https:// doi.org/10.4000/abstractairanica.6445 
Nemūne-hā-yī az qeșse-hā-ye mardom-e İrān. Afsāne-hā va qeșse-hā-ye ìrānì. Gerdāvarande Afšìn Nāderī, bar pāye-ye asnād-e Pažūheškade-ye Mardom-šenāsī, Sāzmān-e Mīrātê-e Farhangī-e Kešvar, Tehrān, Našr-e Qeșṣe, 1383/2004, 432 p. (table de transcription, glossaire, index).

Marina Gaillard

Ce volume s'inscrit dans une série de publications qui présentent chacune, au fur et à mesure de leur parution, un certain nombre des 970 contes collectés à travers l'Iran en 1373/1994 et 1374/1995 pour l'essentiel, sous l'égide de l'Iranian Cultural Heritage Organization (voir Abs.Ir. 24, 2001, c.r. $n^{\circ} 215$ et 25, 2002, n²78). Quatre recueils consacrés aux contes d'une province iranienne en particulier sont déjà parus, ainsi qu'un volume de contes de différentes régions auquel fait suite le présent ouvrage. Celui-ci est aussi le premier dans lequel est donnée la référence au conte-type selon la classification de Aarne et Thompson. Les textes sont précédés de renseignements portant, selon les cas, sur le nom, l'âge et la profession du conteur, le lieu où le conte a été recueilli, la date à laquelle il a été enregistré, la catégorie dont il relève, le nom du ou des collecteurs ; devant la mention du conte-type, un astérisque signale, quand il y a lieu, la correspondance avec les contes répertoriés par U. Marzolph (Typologie des persischen Volksmärchens, 1984, trad. persane 1371/1992). Du fait de leurs natures diverses, les textes sont regroupés d'une part selon les catégories établies par Aarne et Thompson : contes merveilleux, contes facétieux, contes d'animaux, contes énumératifs 
(ou randonnées), d'autre part selon leur forme ou leur thème: contes «de la non existence " (trois contes facétieux réunis sous ce titre), chansons populaires, légendes de la création, allégories et anecdotes morales (catégorie un peu confuse où se rencontrent des textes variés de nature parfois indéterminée dont des " récits courts ", dénomination fréquemment utilisée dans le recueil et qui aurait mérité d'être définie). L'ouvrage fournit en outre des indications utiles : différents termes et expressions sont expliqués en note ; la prononciation dialectale de certains mots est indiquée à l'aide de la vocalisation en persan et/ou d'une transcription, et plusieurs passages, comme des chansons populaires, sont donnés avec la transcription en regard. On s'accordera aisément à reconnaître que la sauvegarde de ce patrimoine folklorique est une excellente iniative.

INDEX

Thèmes : 11.1.1. Littérature persane classique

\section{AUTEURS}

MARINA GAILLARD

CNRS - Paris 